\title{
The level of new science leadership behaviors of school principals: A scale development
}

\author{
Şerife Akpil ${ }^{1}$ and Hasan Basri Gündüz ${ }^{1 a}$ \\ ${ }^{1}$ Yildiz Technical University, Faculty of Education, İstanbul, 34 34220, Turkey
}

\begin{abstract}
Einstein's theory of relativity and quantum physics opened Newton physics up for discussion, thus triggering the new science at the beginning of the 20th century. Philosophy of science, which was named as the new science in the 20th century, caused fundamental changes in research methods and paradigms. The methods and set of values brought by the new science affected social sciences as well. In conjunction with this mentioned change and development, the field of education and the view of schools were influenced. In the same vein, identifying the thoughts of school principals on leadership styles based on new science was considered as a primary need and set the objective of this research. In this regard, a "The Levels of New Science Leadership Behaviors of School Principals Scale" was developed. Following the literature review, the scale with 54 items was prepared and underwent expert review. Finally it was applied to 200 school principals who were working in primary and secondary schools in the Anatolian side of Istanbul. The data acquired were analyzed through SPSS 15.0 and Lisrel 8.51 programs. The results of the analysis revealed that the scale was comprised of a total of 27 items and had 5 factors (dimensions). The reliability analysis indicated internal consistency value (Cronbach Alpha) as .94. Confirmatory factor analysis was carried out in Lisrel program. According to results of confirmatory factor analysis, the $\mathrm{X} 2 / \mathrm{df}$ ratio was calculated as 2, 24 which showed that the measurement model was in accord with the data.
\end{abstract}

Keywords: leadership in new science; leadership in new science scale; school principals, quantum leadership

\section{Introduction}

The effort of humankind to reach information can be considered as an age-long scientific adventure. Evolving through different scientific paradigms and methods in time, this quest first reached Newton's perspective which was named modernism. Newton's perspective was based on Greek philosophy [1, 10]. According to Plato, the real can be reached by

\footnotetext{
a Corresponding author: hgundus@gmail.com
} 
mind [28]. Differing from Plato's idealism, Aristoteles suggested the idea of physics for the first time, thus laying the foundations of the concept of causality [19]. Galileo's integrating mathematics and scientific experiment was the first time experiment was emphasized in science [17]. It can be said that Descartes and Bacon also contributed to the formation of conceptual framework of modern science [6].

According to the world view emerged and developed along with the fundamental principles of Newton's physics, universe is a mechanical system functioning in mathematical laws. If the state of a particular element is known in detail, the future of that element can also be pinpointed. The future is built with the functionality of the set of simple rules $[18,20]$. According to Newton's perspective, nature is so universal, deterministic, objective and in a state of wholeness not limited by the notion of time that it can seem the same to different observers [25].

Einstein's theory of relativity and quantum physics opened Newton physics up for discussion, thus triggering the new science at the beginning of the 20th century [4, 12 and 13]. Instead of a firm determinism, quantum physics draws attention to the uncertainty and probability behind reality, chaos mathematics, the order behind chaos and complexity science, as well as the self-organizing structures at the core of complexity [21]. Newton's point of view based on atom, determination, reduction, precision and predictability started to be replaced by the idea that universe has a nature which is alive, dynamic, integrative, unclear, non-linear and self-organizing.

Quantum physics revealed that universe cannot be analyzed through separating into fractions in a mechanic point of view [29]. Space and time not only affects everything, but also gets affected by everything. There is no universal present time; space and time are dynamic. The previous idea that there is an unchanging universe has given its place to the notion of a dynamic and irreversibly expanding universe with a possibility of starting before a finite time and ending after a finite time $[5,11]$. With quantum and the theory of relativity, the idea that the observer is in the world that is observed and the "human" side of physics can be seen [25]. Thus, the universe can be considered as a vivid and emergent system that goes beyond the difference between physical and social sciences [26].

This philosophy of science led to fundamental changes in social sciences paradigms and methods in the 21 st century [10, 19 and 28]. The application of new science in social systems occurred via sciences related to physics such as chaos theory, self-organizing systems and quantum physics [16, 30]. This idea highlighted the importance of inter subjectivity, context, multiple worlds and ideas, nonlocal reasons and collusion [9, 14 and 23]. The process of leadership gains importance when organization is handled in this context.

Under this new paradigm, prediction and determinism are a myth. Leaders begin with a strong intention, not a set of action plans. Leaders must have confidence in the organizations' intelligence. The future is unknown, but they believe the system is talented enough to organize in the way the future requires [30]. Employees are encouraged to consistently seek out new and discomforting information that challenges the equilibrium of the organization. Many educational leaders view the application of the new sciences to educational leadership with undisguised skepticism [22].

In this regard, studying the process of organizational behavior and leadership in new science is thought to be an important necessity. By the nature of education, the evaluation of principals through new science can be considered an investment in the future. There have been a lot of research carried out through the perspective of new science in the world $[3,7$, 22 and 30] and in Turkey [8, 15, 24 and 27]. However, there has not been an example of a scale addressing the school principals' leadership behaviors in Turkey from the perspectives of Turkish culture and new science. In this vein, the aim of the study is to identify school principals' level of new science leadership behaviors. Becker's [3] new 
science theoretical structure is adopted in this study. According to Becker [3], new science is comprised of five elements; "uncertainty and unpredictability", "complementarity", "semantic and chaotic complexity", "wholeness and implicate order", "non-linear adaptive networks". Identifying school principals" new science leadership behaviors is regarded significant in that it has the potential to be a source for other relevant research and present important data to theoreticians and practitioners beyond being merely an assessment.

\section{Method}

\subsection{Study group}

The data were collected from 200 school principals working in primary and secondary schools of Anatolian side of Istanbul who voluntarily took part in the study in 2014-2015 educational year.

\subsection{Process}

The phases followed in the process of data collection are presented below. Studying the basic theories of new science such as quantum, relativity, and chaos and complexity, the researchers came up with 54 items on leadership in new science, after which they received expert review. These 54 items were written in relation with Becker's 5 dimensions in new science; uncertainty and unpredictability, complementarity, chaotic complexity, integrity and embracing order, non-linear harmonic networks. Corrections were made on some items as a result of expert review and 54 items were organized for the participants to choose one of the options; "strongly agree", "agree", "neutral", "disagree" and "strongly disagree". The scale was applied to school principals in 2014-2015 fall term. In New Science Leadership Scale a total of 5 dimensions and 54 items were included. It was organized in Likert Scale type and expert review was obtained in content validity.

The data were processed in SPSS program. As they had negative meaning, items 9, 21, 33, 44 and 54 were coded inversely in SPSS. Scale reliability analysis and factor analysis were used in SPSS for) predictive analysis. In SPSS 15.0, the collected data were first processed through exploratory factor analysis, then Lisrel 8.51 program was used for confirmatory factor analysis.

\section{Findings}

\subsection{Exploratory factor analysis}

First of all, Kaiser-Mayer-Olkin (KMO) and Barlett Test of Sphericity were studied for factor analysis compliance. For the factor analysis to be used, KMO value must be over 60 and Barlett Test of Sphericity must be significant (Baykul \& Güzeller, 2014). KMO value was .84 in this study. A result close to or over .90 is considered to be a very good result (Baykul \& Güzeller, 2014). A significant result of .001 was found at the Barlet Test of Sphericity. KMO test result and Barlet Test of Sphericity result were parallel and significant. 
Table 1. Factor analysis results of level of new science leadership behaviors of School principals scale

\begin{tabular}{|c|c|c|c|c|c|c|c|}
\hline Factor & Item $\mathrm{N}$. & F1 & F2 & F3 & F4 & F5 & $\begin{array}{l}\text { Variant } \\
\text { Explained }\end{array}$ \\
\hline \multirow{5}{*}{ I } & M3 & 0,57 & & & & & \\
\hline & M4 & 0,76 & & & & & \\
\hline & M5 & 0,79 & & & & & 14,9 \\
\hline & M7 & 0,70 & & & & & \\
\hline & M9 & 0,57 & & & & & \\
\hline \multirow{5}{*}{ II } & M15 & & 0,75 & & & & 13,9 \\
\hline & M16 & & 0,75 & & & & \\
\hline & M17 & & 0,74 & & & & \\
\hline & M18 & & 0,63 & & & & \\
\hline & M20 & & 0,56 & & & & \\
\hline \multirow{5}{*}{ III } & M23 & & & 0,78 & & & 13,7 \\
\hline & M24 & & & 0,76 & & & \\
\hline & M29 & & & 0,66 & & & \\
\hline & M30 & & & 0,72 & & & \\
\hline & M31 & & & 0,66 & & & \\
\hline \multirow{6}{*}{ IV } & M38 & & & & 0,65 & & 12,7 \\
\hline & M40 & & & & 0,69 & & \\
\hline & M41 & & & & 0,64 & & \\
\hline & M42 & & & & 0,77 & & \\
\hline & M43 & & & & 0,66 & & \\
\hline & M44 & & & & 0,77 & & \\
\hline \multirow{8}{*}{ V } & M46 & & & & & 0,60 & 11,6 \\
\hline & M47 & & & & & 0,75 & \\
\hline & M48 & & & & & 0,73 & \\
\hline & M49 & & & & & 0,74 & \\
\hline & M52 & & & & & 0,55 & \\
\hline & M53 & & & & & 0,71 & \\
\hline & Kaiser-1 & Dlkin: & & & & & 66,8 \\
\hline & Batlett's & $\mathrm{f} \mathrm{Sph}$ & $: 0,00$ & & & & \\
\hline
\end{tabular}

\subsection{Confirmatory factor analysis}

At the end of confirmatory factor analysis, it was found that the scale has the best structure with 5 factors and the remaining 27 items generally met the fit indixes after the modifications. 


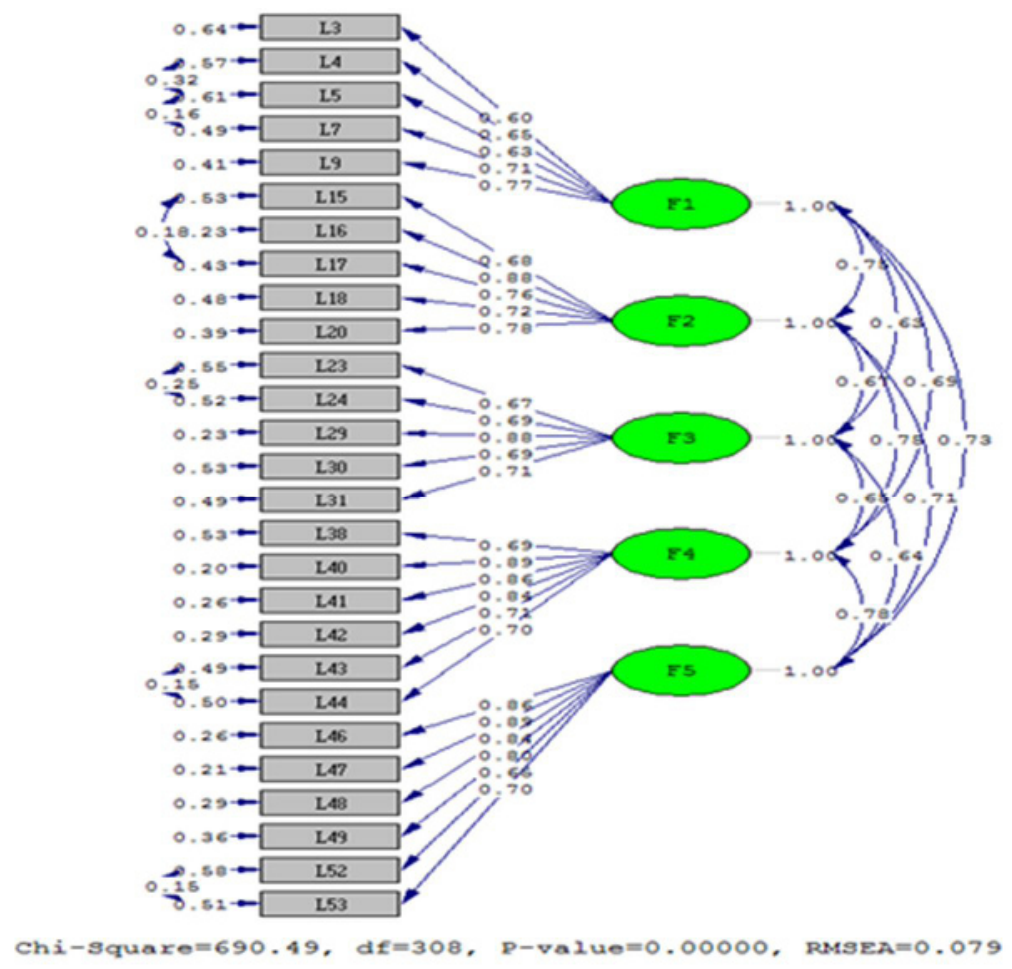

Fig 1. The level of new science leadership behaviours of school principals DFA results

\subsection{Reliability of new science leadership scale}

Cronbach Alpha coefficient of the scale was found 0.94 which is considered quite high. Cronbach Alpha coefficient values of the sub-dimensions were calculated as respectively $0,79-0,86-0,79-0,85-0,87$. It is seen that in leadership scale, total correlation for all items change between $0,45-0,77$ and $t$-scores of all items were significant $(p<0,01)$. When paired tests correlations of dimensions and scales (Spearman Brown) results are studied, Paired tests correlations are 0,87 ; dimensions correlation results are $0,81-0,85-0,78-0,82$, 0,87 . It can be interpreted by the results that the validity of the items in the scale was high and distinguishing in terms of leadership perception, and the items in the scale were directed at measuring the same behavior in the scale.

\section{Discussion and conclusion}

In the study, "The Levels of New Science Leadership Behaviors of School Principals Scale" was developed with the aim of identifying the levels of school principals' new science leadership behaviors. Firstly, a five factor structure was obtained through exploratory factor analysis in the process of developing the scale. The structure obtained through exploratory factor analysis was tested in terms of model fit through confirmatory factor analysis. As a result of exploratory and confirmatory factor analyses, the 27 items and five factors model was found to be theoretically and statistically appropriate. Besides, these results are proof that the scale is valid structurally. When the internal consistency is studied within reliability, it was found that the scale was reliable. 
As a result of this study, The Levels of New Science Leadership Behaviors of School Principals Scale was found to be a valid and reliable scale that can be used to identify primary and secondary school principals' levels of new science leadership behaviors. The distribution of items in the scale by factors: Items 3, 4, 5, 7 and 9 measure "Uncertainty and Unpredictability", items 15, 16, 17, 18 and 20 measure "Complementarity", items 23, 24, 29, 30 and 31 measure "Semantic and Chaotic Complexity", items 38, 40, 41, 42, 43 and 44 measure "Wholeness and Implicate order", and items 46, 47, 48, 49, 52 and 53 measure "Non-linear Adaptive Networks".

The lowest and highest possible scores of the scale are 27 and 135. If the total score of the scale is divided by the number of items (27), a conclusion about the level of school principals' new science leadership behaviors can be arrived. At the end of this operation, below 2.5 means high, between 2.5 and 3.5 means medium, and over 3.5 means low level of leadership behavior in new science. As the numbers go up, the leadership behavior in new science goes up. The valid and reliable scale developed in this study can be used in identifying the levels of school principals' new science leadership behaviors in relevant literature.

\section{References}

1. Arı, V. (2015). Evrenin gerçekliği. İstanbul: Bilgi Üniversitesi Yayınları.

2. Baykul, Y. ve Güzeller, C. O. (2014). Sosyal bilimler için istatistik. Ankara: Pegem Yayınları.

3. Becker, P.H. (2006). "New science" as a lens through which to view change in a university facilities management division: Complexity, wholeness, and implicate order. Unpublished doctoral thesis, University of Saskatchewan, Canada

4. Capra, F. (2012). Batı düşüncesinde dönüm noktası. (M. Armağan, Çev.). İstanbul: İnsan Yayınları, (1992).

5. Davies, P. (2014). Tanrı ve yeni fizik. (B. Gönülşen, Çev.). İstanbul: Alfa Basım Yayım Dağıtım. (1983).)

6. Demir, Ö. (2012). Bilim felsefesi. Bursa: Sentez yayıncılık.

7. Doberneck, D. M. (2003). The complexity sciences as an emerging organizational paradigm in higher education: An exploratory study. Unpublished doctoral thesis, Michigan State University.

8. Erçetin, Ş.Ş. and Kamacı, M.C. (2008) Quantum leadership paradigm. World Applied Sciences Journal, 3(6), 865-868.

9. Gleick, J. (2014). Kaos. (İ. A. Demir, Çev.). İstanbul: Alfa Basım Yayım Dağıtım. (1987).

10. Güzel, C. (2013). Bilim felsefesi. Ankara: Bilgesu Yayınları.

11. Hawking, S. (2014). Zamanın kısa tarihi. (B. Gönülşen, Çev.). İstanbul: Alfa Basım Yayım Dağıtım. (1988).

12. Horgan, J. (1997). The end of science. New York: Broadway Books.

13. Horgan, J. (2015). The end of science: Facing the limits of knowledge in the twilight of the scientific age. USA: Basic Books.

14. Işıklı, Ş. (2012). Kuantum felsefesi postmodern bilimin doğuşu. Ankara: Birleşik Yayınevi.

15. Keskinkılıç Kara, S. B. (2013). Yeni bilim ve liderlik. Akademik Bakış. 34, 1 -13.

16. Kiel, L.D. (1994). Managing chaos and complexity in government: A new paradigm for managing change, innovation, and organizational renewal. San Francisco, CA: Jossey-Bass.

17. Koyre, A. (2000). Yeniçağ biliminin doğuşu. (K. Dinçer, Çev.) Ankara: Gündoğan Yayınları. 
18. Laughlin, R.B. (2015). Farklı bir evren: Fiziği en baştan icat etmek. (U. Apak, Çev.). İstanbul: Alfa Bilim Yayıncılık.

19. Lecourt, D. (2006) Bilim felsefesi, (I. Ergüden, Çev.), Ankara: Dost Kitabevi Yayınları, (2001).

20. Merdin, S. (2012). Tanrıyı arayan fizik. İstanbul: Ozon Yayıncılık.

21. Obolensky, N. (2014). Complex adaptive leadership: Embracing paradox and uncertainty. Burlington: Gower publishing Company.

22. Owen, R.C. (2008). New sciences-based leadership and student success in Californa's community colleges. Unpublished doctoral thesis, University of La Verne.

23. Overman, E.S. (1996). The new science of administration: Chaos and quantum theory. Administration Review, 56(5), 487-491.

24. Papatya, G. and M. A. Dulupçu. (2000). Thinking quantum leadership for true transformation: The talisman of "not to know" at the threshold of new leadership. International Joint Symposium on Business Administration, Gökçeada, Çanakkale Onsekiz Mart University-Silesian University.

25. Prigogine, I. and Stengers, I. (1996). Kaostan düzene. (S. Demirci, Çev.). İstanbul: İz Yayıncılik (1984).

26. Senge, P., Scharmer, C. O., Jaworski, J., \& Flowers, B. S. (2004). Presence. Human purpose and the field of the future. Cambridge: The Society for Organizational Learning.

27. Tüz, M. (2004). Degisim ve kaos ortamında işletme davranısı. İstanbul: Alfa Basım.

28. Yıldırım, C. (2012). Bilim felsefesi. İstanbul: Remzi Kitabevi.

29. Wolf, F. A. (2014). Kuantum bilmecesi: Bilimci Olmayanlar için yeni fizik, (M. Doğan, Çev.). İstanbul: Omega Yayınları. (1981).

30. Wheatley, M. (2005). Finding our way. Leadership for an uncertain time. San Francisco: Berrett-Koehler Publishers, Inc. 